\title{
Supplement to "Extreme warming restructures habitat distribution and productivity along local gradients in stress and biodiversity" v1
}

\author{
Matthew Whalen ${ }^{1}$ \\ ${ }^{1}$ Affiliation not available
}

June 4, 2021

\section{Supplemental Material}

Table S1. Range of sampling dates for intertidal biodiversity surveys in each year

\begin{tabular}{|c|c|c|}
\hline & \multicolumn{2}{|c|}{ Year Date range } \\
\hline 2012 & 03 July & 05 July \\
\hline 2013 & 23 May & 26 Мay \\
\hline 2014 & 12 June & 14 June \\
\hline 2015 & 14 June & 16 June \\
\hline 2016 & 05 June & 07 June \\
\hline 2017 & 24 May & 26 May \\
\hline 2018 & 12 June & 14 June \\
\hline 2019 & 01 June & 04 June \\
\hline
\end{tabular}

Regional measures of sea surface temperature, atmospheric temperatures, and waves

The 2014-2016 marine heatwave began with the formation of a warm 'blob' off of the west coast of North America, which was followed by an intense El Niño (Di Lorenzo \& Mantua 2016). This led to a multiyear MHW that was strongly felt along Central Coast BC. Air and water temperature measurements from three $\mathrm{BC}$ lightstations illustrate the scale and severity of the heatwave in this region (Fig. 1). The heatwave was sustained from May 2014 to November 2017, longer than sites further south (e.g., California and Mexico: (Arafeh-Dalmau et al. 2019; Sanford et al. 2019) but consistent with patterns elsewhere on the BC coast (Starko et al. 2019). In a similar fashion, air temperatures were anomalously high from early 2014 through the end of 2016, demonstrating that this heatwave was extreme both oceanographically and atmospherically (Swain et al. 2017). This MHW rivaled the severity of the 1997/1998 El Niño for both air and water temperature in this region and represents the longest set of heatwaves in a time series of SST dating to the 1930s (Fig. S1). During the heatwave, daily SST and air temperature anomalies regularly exceeded $2.5^{\circ} \mathrm{C}$.

Atmospheric temperatures on Calvert Island during the study period also reflect the anomalous conditions of the 2014-2016 NE Pacific MHW (Fig. S4). Temperatures tended toward positive temperature anomalies relative to mean conditions from Fall 2014 through Spring 2016.

Local intertidal temperatures 
Temperature loggers were wrapped in parafilm and placed inside a PVC cap that was spray painted black and fastened to the substratum using a bolt, wall-anchor and marine epoxy. Temperature was then logged every 4 hours. From July 2012 to May 2013, we also measured intertidal temperatures in the high zone at Foggy Cove, but the cap was the blue top from a Falcon tube (Fisher Scientific). We anticipate differences due to the material of the cap, how it was affixed to the rock, and the precise location of the logger, therefore we do not formally compare 2012-2013 data with those from 2014-2016.

Temperature data collected in situ during the study were not sampled over a sufficiently long time period to allow similar retrospective analysis as we performed with data from BC lightstations, but they offer a glimpse into local temperatures during the heatwave that are relevant to intertidal organisms, as well as important differences in thermal environments among sites. Local intertidal temperatures measured in one transect from Foggy Cove before (2012-2013) and during the heatwave (2014- 2016) spanned a range of over 30degC (Fig. S3). Winter temperatures from 2015 were $1 \operatorname{deg} \mathrm{C}$ warmer than the winter of 2016. Additionally, in situ temperatures in the late summer of 2015 more often exceeded the $75^{\text {th }}$ quartile than in 2014 , suggesting that high intertidal conditions in 2015 was more stressful than in 2014. Although we cannot directly compare the temperature data from before and during the heatwave, our data suggest that variance in intertidal temperatures may have increased during the heatwave. Rock temperatures were also highly variable across the three sites in our study area based on data from 2015-2016 (Fig. S4). North Beach experienced much longer durations of temperatures exceeding $20 \mathrm{deg}$ and $30 \mathrm{degC}$ than either other site, while Fifth Beach was the only site to never experience in situ temperatures exceeding 30degC during the 2015 deployment. These differences are likely attributable to the physical setting of each site. North Beach faces west and has no barriers to sunlight on clear days, while Fifth Beach faces north and is backed by a vegetated bluff that blocks direct sunlight for much of the day. Foggy Cove differs from the two other sites in that its slope is shallower than the other sites and is characterized by boulders rather than a contiguous rocky outcrop, suggesting a different abiotic stress gradient over similar spatial extents (Fig. S1).

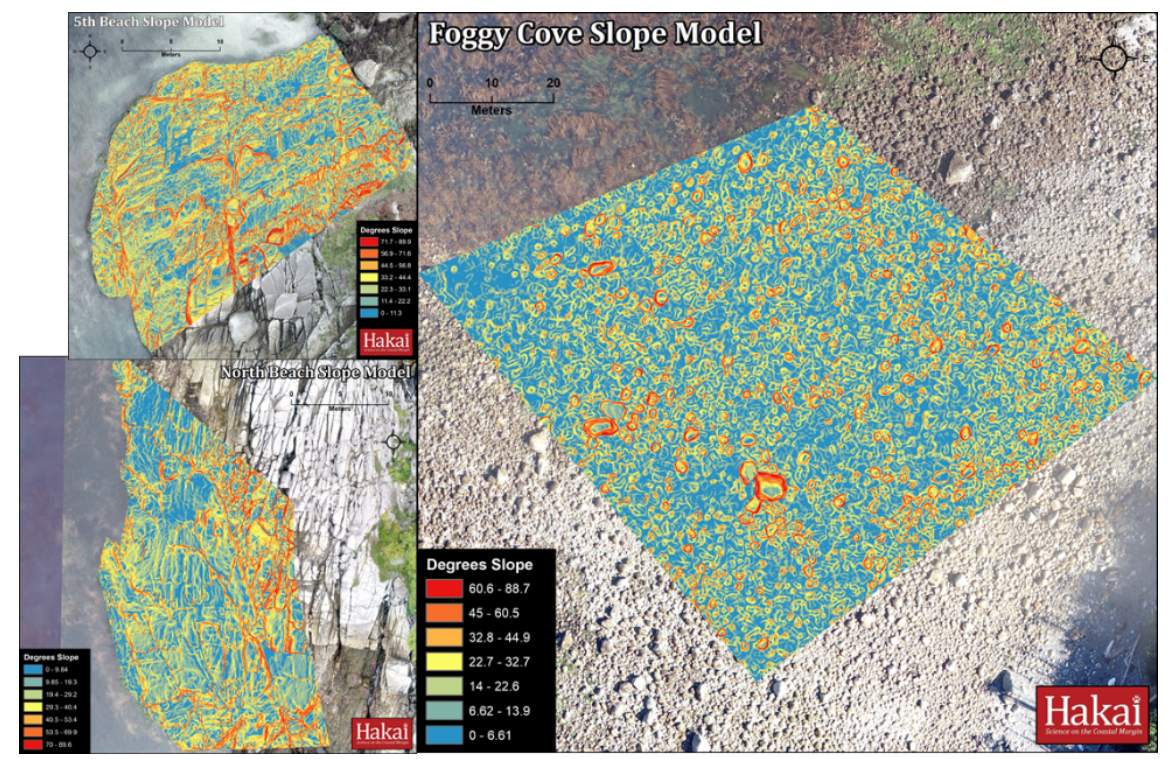

Fig. S1. Digital elevation models for the three sites in this study. Colors in all panels represent local slope estimates ranging from 0 to 90 degrees, where 0 degrees is parallel with a level horizontal plane. Note that the spatial scale of the image is different for Foggy Cove. 

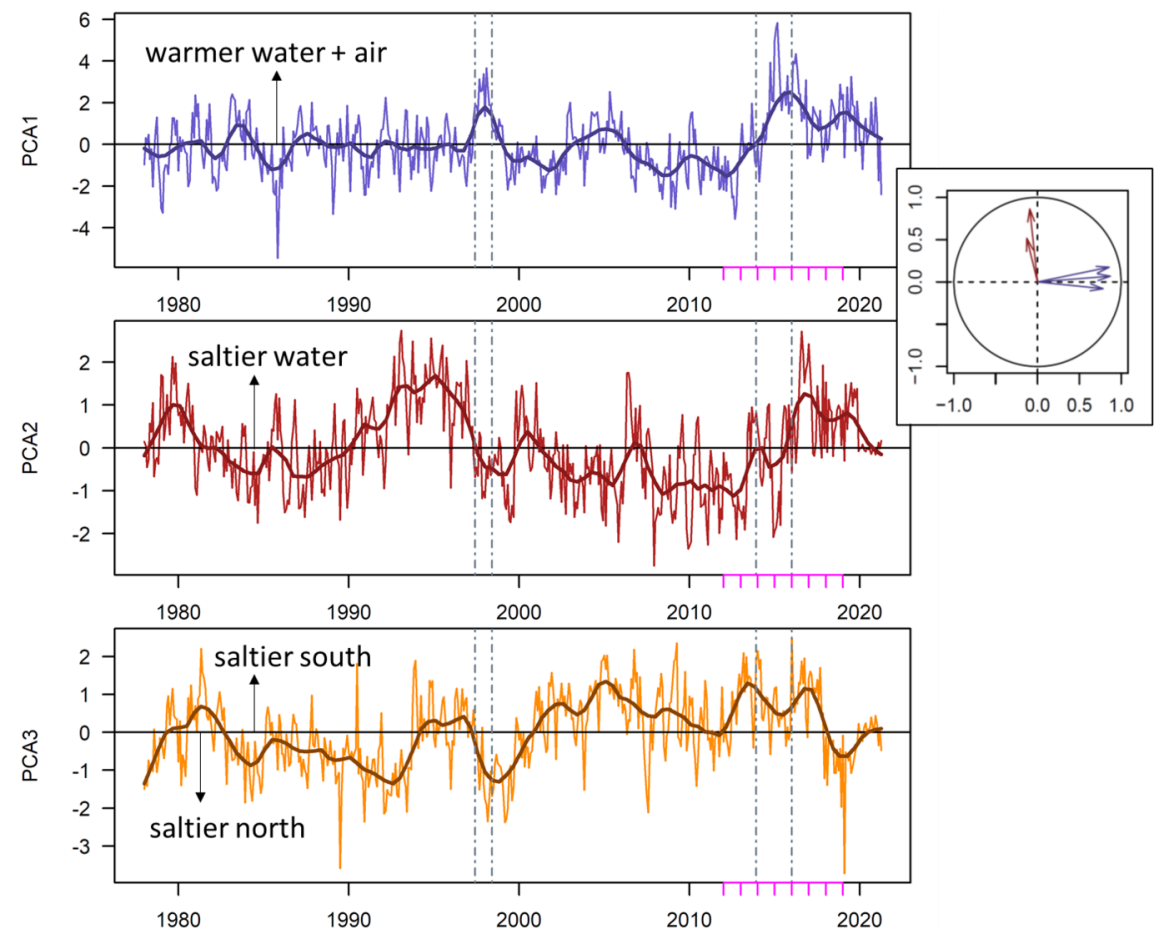

Fig. S2. Temporal change in the first three axes of a principal components analysis (PCA) on five environmental variables: monthly temperature anomalies at three lightstations (sea surface temperature at Pine and McInnes Islands, air temperature at Addenbroke Island) and moshtly surface salinity anomalies at Pine and McInnes Islands. The PCA used only times shared by all datasets (1978-2020), but anomalies are calculated from all available data. Lighter lines show monthly PCA values, while the darker lines are LOESS smoothers. Survey years are noted with magenta tick marks. Note how anomalous conditions continued in the region, even after the 2014-2016 marine heatwave ended elsewhere.
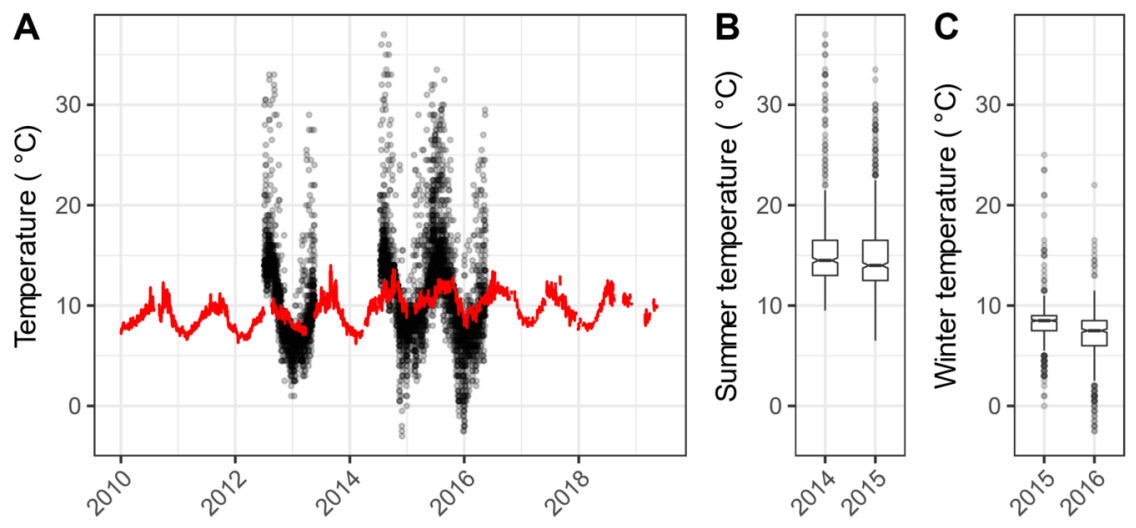

Fig. S3. (A) comparison of in situ temperature data from Foggy Cove (black points) and SST data from the Pine Island lightstation (red line; see Fig. 1, Fig. S2). Individual temperature records are shown for both datasets: in situ data were collected every 4 hours, while lightstation SST is recorded once daily when a keeper is present. Boxplots show the distributions of summer (B, July through September) and winter (C, December through February) in situ temperatures at Foggy Cove from 2014 to 2016. 


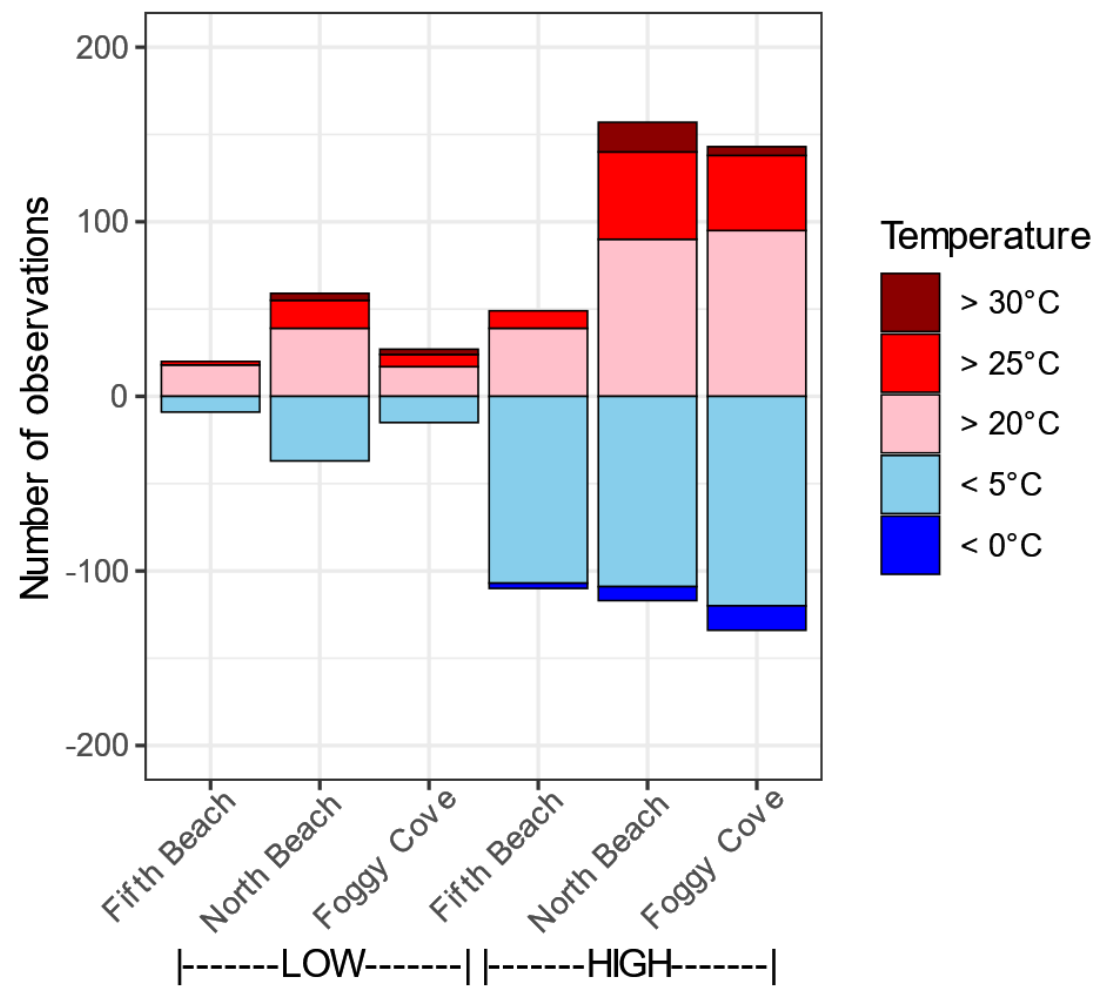

Fig. S4. Temperature logger measurements collected between June 2015 and May 2016 in LOW and HIGH zones at each study site. Bars show the number of observations (taken every four hours) above and below several thresholds for each logger.

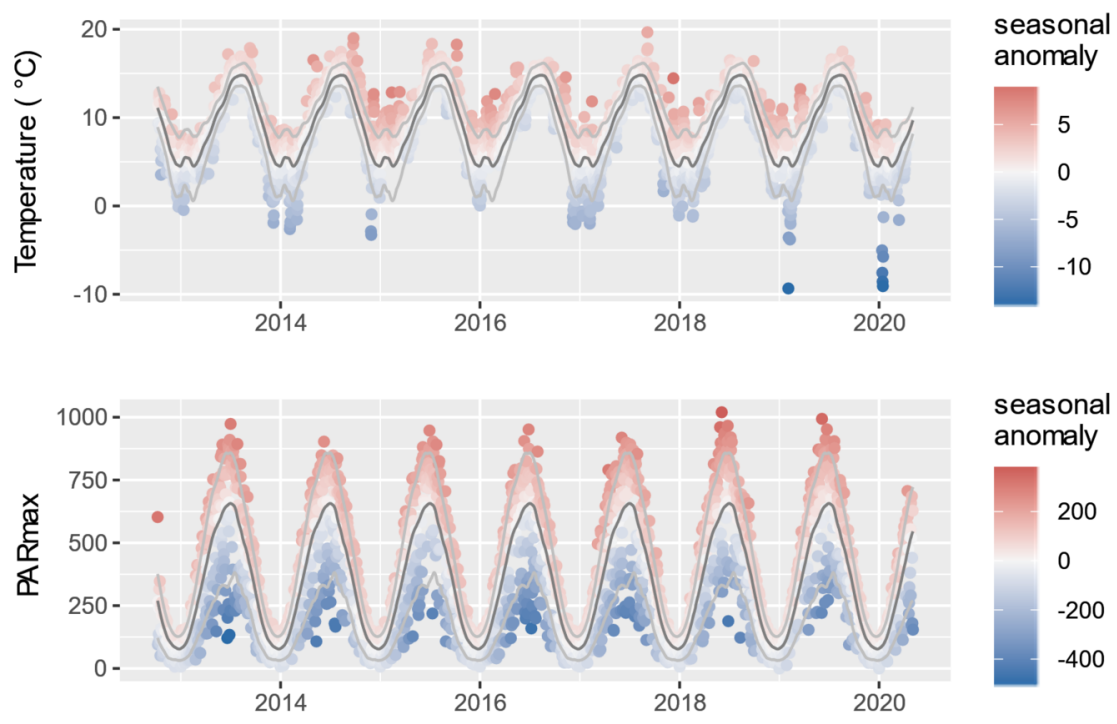

Fig. S5. Hourly atmospheric temperature and hourly maximum photosynthetically active radiation (PARmax) records collected since October 2012 at a weather station on Calvert Island. Black line shows the 
seasonal trends, and color of data points represent anomalies from the seasonal trend. The weather station is located above Foggy Cove at $63 \mathrm{~m}$ above sea-level at the top of a nearby hill that is often above the fog layer

Selection of taxa: Because we were interested in modelling species abundance as a function of year, we could only include species that occurred fairly regularly. The rarest taxa were not included in the joint species distribution modeling with HMSC. We could have included those species, but we would have had far less certainty about distributional patterns in any one year, as well as patterns across years. Therefore, we set an arbitrary threshold that species must have occurred in at least 48 plots throughout the entire time series, which equates to an average of 6 quadrats per year. This threshold left a minimum of XX observations in any year and a minimum of XX percent cover in any year.

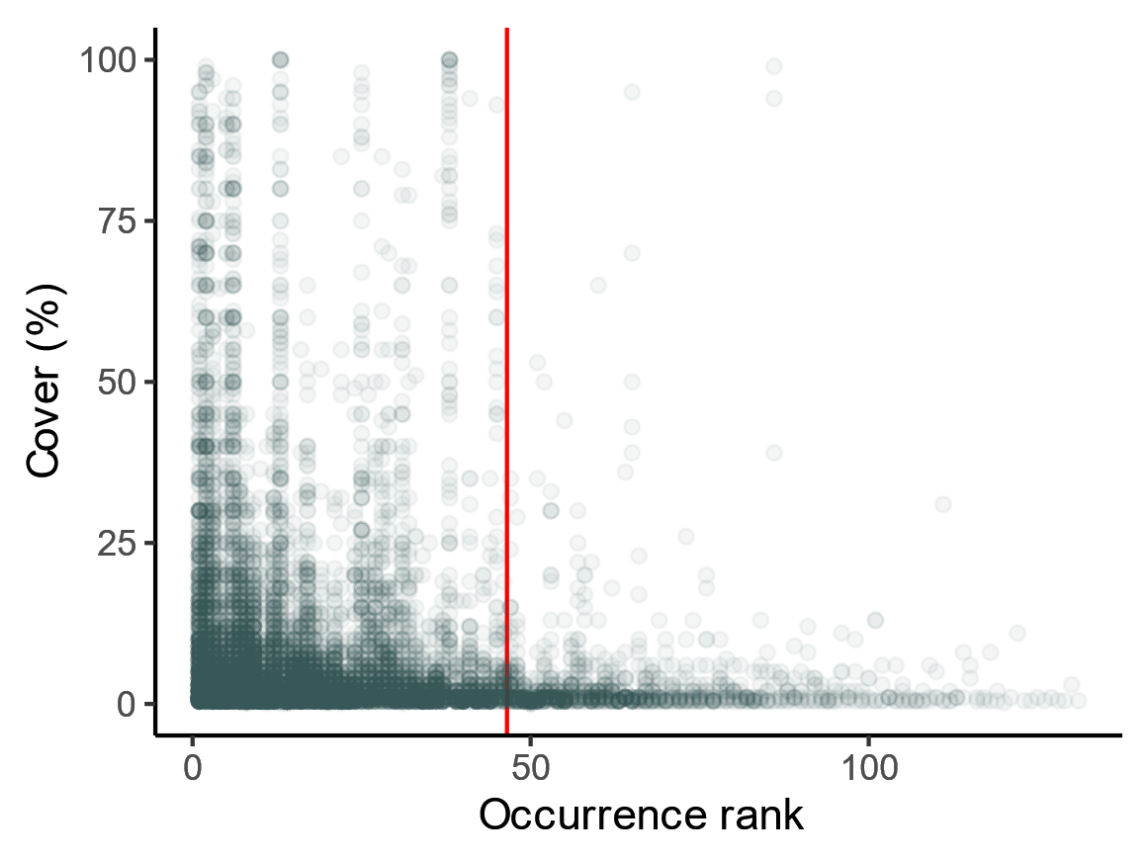




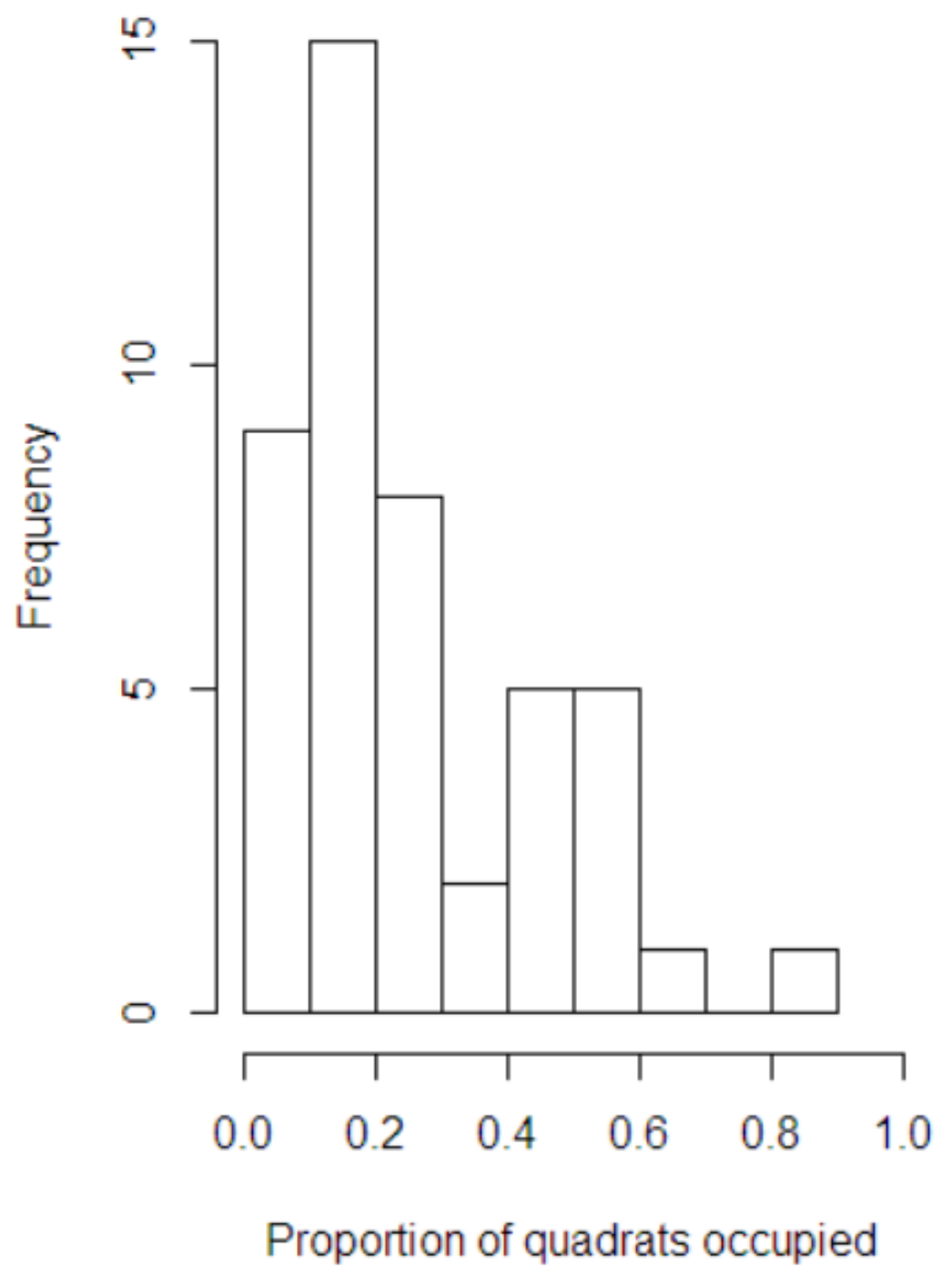

Fig. S6. Summary of cover for all taxa ordered by average occurrence in the dataset. The red line shows the threshold for inclusion in HMSC analysis. The inset figure shows the frequency of occurrence across taxa.

Supplemental Table 2. List of all taxonomic names used in the analyses. Taxa used in HMSC modeling are the first 47 taxa, while other taxa were used in analyses of total cover, species richness, and community composition. The trophic position and functional group designation of each taxon is also provided.

\begin{tabular}{llllll}
\hline & rank & taxon & HMSC & trophic position & functional group \\
1 & 1 & Hildenbrandia spp. & yes & producer & crust \\
2 & 2 & Fucus distichus & yes & producer & canopy
\end{tabular}




\begin{tabular}{|c|c|c|c|c|c|}
\hline 3 & 3 & Pyropia spp. * & yes & producer & blade \\
\hline 4 & 4 & Mastocarpus spp. & yes & producer & turf \\
\hline 5 & 5 & Mastocarpus spp. (crustose "Petrocelis" phase) & yes & producer & crust \\
\hline 6 & 6 & Barnacles** & yes & consumer & animal \\
\hline 7 & 7 & Corallina spp. & yes & producer & turf \\
\hline 8 & 8 & Endocladia muricata & yes & producer & thin turf \\
\hline 9 & 9 & Chamberlainium tumidum & yes & producer & crust \\
\hline 10 & 10 & Ulva spp. & yes & producer & blade \\
\hline 11 & 11 & Halosaccion glandiforme & yes & producer & turf \\
\hline 12 & 12 & articulate Bossiella spp. & yes & producer & animal \\
\hline 13 & 13 & Alaria marginata & yes & producer & canopy \\
\hline 14 & 14 & Acrosiphonia spp. & yes & producer & thin turf \\
\hline 15 & 15 & Anemone & yes & consumer & animal \\
\hline 16 & 16 & coralline crust & yes & producer & animal \\
\hline 17 & 17 & Plocamium violaceum & yes & producer & thin turf \\
\hline 18 & 18 & Mazzaella oregona & yes & producer & blade \\
\hline 19 & 19 & Microcladia borealis & yes & producer & thin turf \\
\hline 20 & 20 & Callithamnion pikeanum & yes & producer & thin turf \\
\hline 21 & 21 & Cryptosiphonia woodii & yes & producer & turf \\
\hline 22 & 22 & Gloiopeltis furcata & yes & producer & thin turf \\
\hline 23 & 23 & Leathesia marina & yes & producer & turf \\
\hline 24 & 24 & Hymenena spp. & yes & producer & turf \\
\hline 25 & 25 & Phyllospadix spp. & yes & producer & canopy \\
\hline 26 & 26 & Polyneura latissima & yes & producer & turf \\
\hline 27 & 27 & Mazzaella splendens & yes & producer & blade \\
\hline 28 & 28 & Neorhodomela larix & yes & producer & turf \\
\hline 29 & 29 & Ptilota filicina & yes & producer & thin turf \\
\hline 30 & 29 & Savoiea robusta & yes & producer & thin turf \\
\hline 31 & 31 & Mytilus spp. & yes & consumer & animal \\
\hline 32 & 32 & Odonthalia floccosa & yes & producer & turf \\
\hline 33 & 33 & Elachista fucicola & yes & producer & thin turf \\
\hline 34 & 34 & Cladophora columbiana & yes & producer & thin turf \\
\hline 35 & 34 & Lithothamnion phymatodeum & yes & producer & crust \\
\hline 36 & 34 & Ralfsioid & yes & producer & crust \\
\hline 37 & 37 & Polysiphonia spp. & yes & producer & thin turf \\
\hline 38 & 38 & Hedophyllum sessile & yes & producer & canopy \\
\hline 39 & 39 & Ceramium pacificum & yes & producer & thin turf \\
\hline 40 & 40 & Neopolyporolithon reclinatum & yes & producer & crust \\
\hline 41 & 41 & Neogastroclonium subarticulatum & yes & producer & turf \\
\hline 42 & 42 & Mazzaella parvula & yes & producer & turf \\
\hline 43 & 43 & Prionitis spp. & yes & producer & turf \\
\hline 44 & 44 & Farlowia mollis & yes & producer & turf \\
\hline 45 & 45 & Egregia menziesii & yes & producer & canopy \\
\hline 46 & 46 & Dilsea californica & yes & producer & blade \\
\hline 47 & 47 & Palmaria hecatensis & yes & producer & blade \\
\hline 48 & 48 & Codium fragile & no & producer & turf \\
\hline 49 & 49 & Nemalion helminthoides & no & producer & turf \\
\hline 50 & 49 & Tube worms & no & consumer & animal \\
\hline 51 & 51 & Analipus japonicus & no & producer & turf \\
\hline 52 & 52 & Bryozoan & no & consumer & animal \\
\hline 53 & 52 & Schizymenia pacifica & no & producer & blade \\
\hline
\end{tabular}




\begin{tabular}{|c|c|c|}
\hline 54 & 52 & Tunicata/Porifera \\
\hline 55 & 55 & Scytosiphon lomentaria \\
\hline 56 & 56 & Codium setchellii \\
\hline 57 & 56 & Hedophyllum nigripes \\
\hline 58 & 58 & Costaria costata \\
\hline 59 & 58 & Ectocarpus commensalis \\
\hline 60 & 58 & Osmundea spectabilis \\
\hline 61 & 61 & Peyssonnelia sp. \\
\hline 62 & 62 & Blidingia sp. \\
\hline 63 & 62 & Palmaria mollis \\
\hline 64 & 64 & Dactylosiphon bullosus \\
\hline 65 & 64 & Scytosiphon dotyi \\
\hline 66 & 66 & Calliarthron tuberculosum \\
\hline 67 & 67 & Tokidadendron bullatum \\
\hline 68 & 68 & Unknown crust \\
\hline 69 & 69 & Salishia firma \\
\hline 70 & 70 & Ahnfeltia fastigiata \\
\hline 71 & 70 & Chiharaea silvae \\
\hline 72 & 70 & Cumathamnion decipiens \\
\hline 73 & 70 & Lomentaria hakodatensis \\
\hline 74 & 70 & Mazzaella parksii \\
\hline 75 & 70 & Melanosiphon intestinalis \\
\hline 76 & 70 & Pollicipes polymerus \\
\hline 77 & 77 & Colpomenia peregrina \\
\hline 78 & 77 & Desmarestia ligulata \\
\hline 79 & 77 & Laminaria setchellii \\
\hline 80 & 80 & Chiharaea rhododactyla \\
\hline 81 & 81 & Antithamnionella spp. \\
\hline 82 & 81 & Melobesia sp. \\
\hline 83 & 81 & Smithora naiadum \\
\hline 84 & 84 & Antithamnion defectum \\
\hline 85 & 84 & Johansenia macmillanii \\
\hline 86 & 86 & Erythrotrichia carnea \\
\hline 87 & 86 & Nereocystis luetkeana \\
\hline 88 & 86 & Pylaiella littoralis \\
\hline 89 & 89 & Collinsiella tuberculata \\
\hline 90 & 89 & Hydroid \\
\hline 91 & 89 & Neorhodomela oregona \\
\hline 92 & 89 & Rhodochorton purpureum \\
\hline 93 & 93 & "Bangia" sp. \\
\hline 94 & 93 & Cladophora sericea \\
\hline 95 & 93 & Laminaria yezoensis \\
\hline 96 & 93 & Rhizoclonium tortuosum \\
\hline 97 & 97 & Desmarestia aculeata \\
\hline 98 & 97 & Herposiphonia plumula \\
\hline 99 & 97 & Lithothamnion glaciale \\
\hline 100 & 97 & Opuntiella californica \\
\hline 101 & 97 & Pododesmus sp. \\
\hline 102 & 97 & Soranthera ulvoidea \\
\hline 103 & 97 & Sphacelaria rigidula \\
\hline 104 & 104 & Callophyllis sp. \\
\hline
\end{tabular}

\begin{tabular}{|c|c|c|}
\hline no & consumer & animal \\
\hline no & producer & turf \\
\hline no & producer & crust \\
\hline no & producer & canopy \\
\hline no & producer & canopy \\
\hline no & producer & thin turf \\
\hline no & producer & turf \\
\hline no & producer & crust \\
\hline no & producer & turf \\
\hline no & producer & blade \\
\hline no & producer & turf \\
\hline no & producer & turf \\
\hline no & producer & turf \\
\hline no & producer & turf \\
\hline no & producer & crust \\
\hline no & producer & blade \\
\hline no & producer & turf \\
\hline no & producer & turf \\
\hline no & producer & turf \\
\hline no & producer & turf \\
\hline no & producer & turf \\
\hline no & producer & turf \\
\hline no & consumer & animal \\
\hline no & producer & turf \\
\hline no & producer & canopy \\
\hline no & producer & canopy \\
\hline no & producer & turf \\
\hline no & producer & thin turf \\
\hline no & producer & crust \\
\hline no & producer & blade \\
\hline no & producer & thin turf \\
\hline no & producer & turf \\
\hline no & producer & thin turf \\
\hline no & producer & canopy \\
\hline no & producer & thin turf \\
\hline no & producer & turf \\
\hline no & consumer & animal \\
\hline no & producer & turf \\
\hline no & producer & thin turf \\
\hline no & producer & thin turf \\
\hline no & producer & thin turf \\
\hline no & producer & canopy \\
\hline no & producer & thin turf \\
\hline no & producer & turf \\
\hline no & producer & turf \\
\hline no & producer & crust \\
\hline no & producer & blade \\
\hline no & consumer & animal \\
\hline no & producer & turf \\
\hline no & producer & thin turf \\
\hline no & producer & turf \\
\hline
\end{tabular}




\begin{tabular}{|c|c|c|c|c|c|}
\hline 105 & 104 & Chaetomorpha linum & no & producer & thin turf \\
\hline 106 & 104 & Monostroma grevillei & no & producer & blade \\
\hline 107 & 104 & Neorhodomela aculeata & no & producer & turf \\
\hline 108 & 104 & Odonthalia floccosa f. comosa & no & producer & turf \\
\hline 109 & 104 & Plocamium pacificum & no & producer & thin turf \\
\hline 110 & 104 & Pterocladiella caloglossoides & no & producer & thin turf \\
\hline 111 & 104 & Styela sp. & no & consumer & animal \\
\hline 112 & 113 & Ceramium "codicola" & no & producer & thin turf \\
\hline 113 & 113 & Ectocarpus sp. & no & producer & thin turf \\
\hline 114 & 113 & Mesophyllum vancouveriense & no & producer & crust \\
\hline 115 & 113 & Pterygophora californica & no & producer & canopy \\
\hline 116 & 113 & Symphyocladiella dendroidea & no & producer & animal \\
\hline
\end{tabular}

* Pyropia spp. includes specimens identified asNeoporphyra perforata , Pyropia abbottiae ,Pyropia fallax , Neopyropia fucicola , Pyropia gardneri , Pyropia pulchra, and Wildemania norrisii

** Barnacles include Balanus glandula + Chthamalusdalli + Semibalanus cariosus

Model structure and fit:

We ran HMSC models using the following setup: thin $=100$, transient $=12,500$, samples $=250$. Using four chains to traverse parameter space and sample the posterior distribution of estimates, we obtained a total of 1,000 samples from each species, which we used in downstream analysis and interpretation. Gelman's diagnostic scores were largely within the range of acceptable values (98-99\% of values were $<1.05)$, suggesting that we had reached convergence of the model. Examination of trace plots (not shown here) provided further support that chains were well mixed. 


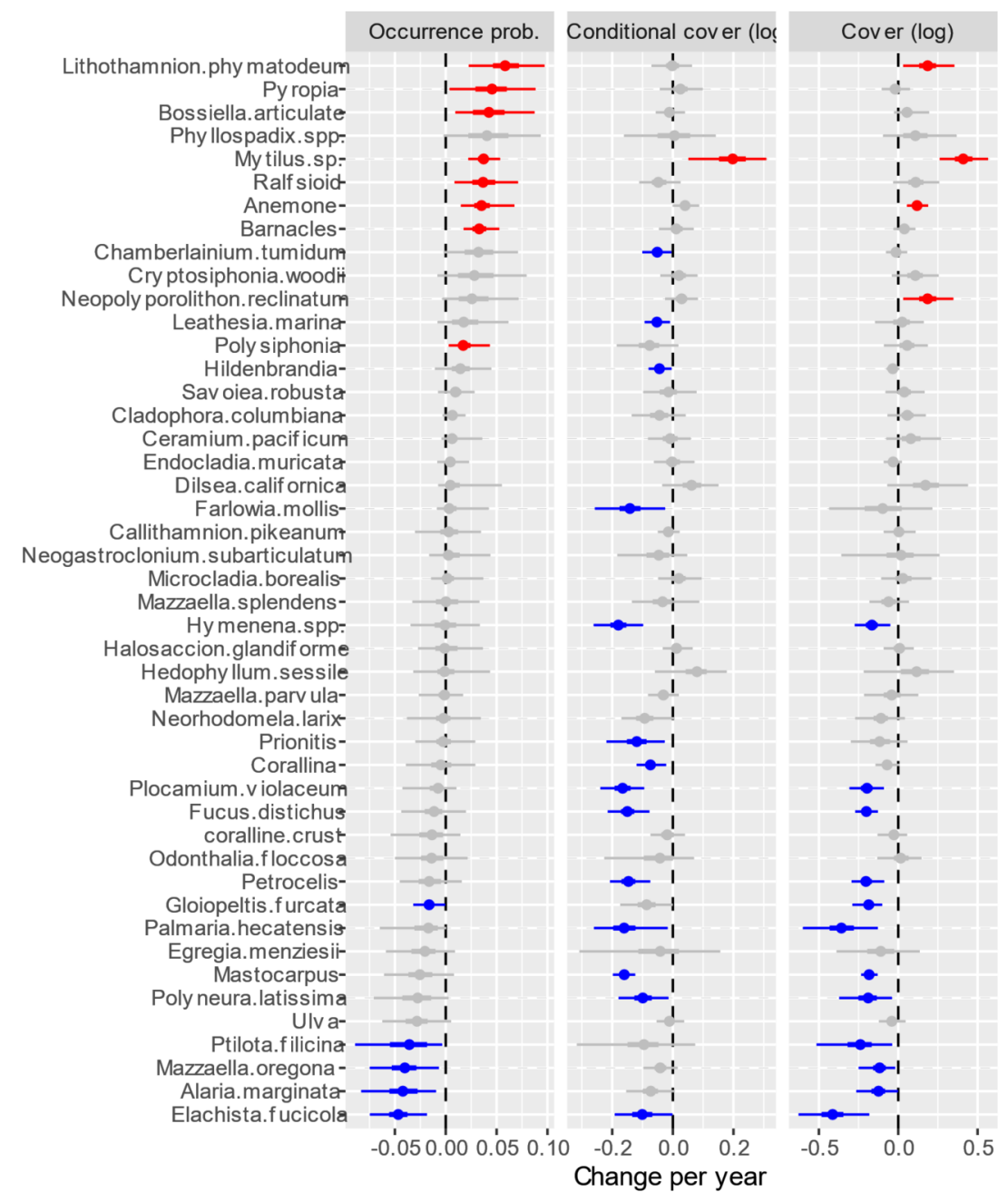

Fig. S7. Summary of temporal trends from HMSC analysis. Colors represent support for positive (red) or negative (blue) linear trends based on overlap of credible intervals with zero (grey). Predictions were averaged over eight uniformly spaced elevations between $61 \mathrm{~cm}$ and $382 \mathrm{~cm}$ above MLLWLT $(69 \mathrm{~cm}, 113$ $\mathrm{cm}, 158 \mathrm{~cm}, 202 \mathrm{~cm}, 246 \mathrm{~cm}, 290 \mathrm{~cm}, 335 \mathrm{~cm}, 379 \mathrm{~cm}$ ), weighted by the proportion of sampled elevations in the dataset (proportion [?] 0.11, 0.17, 0.13, 0.24, 0.17, 0.09, 0.08). 


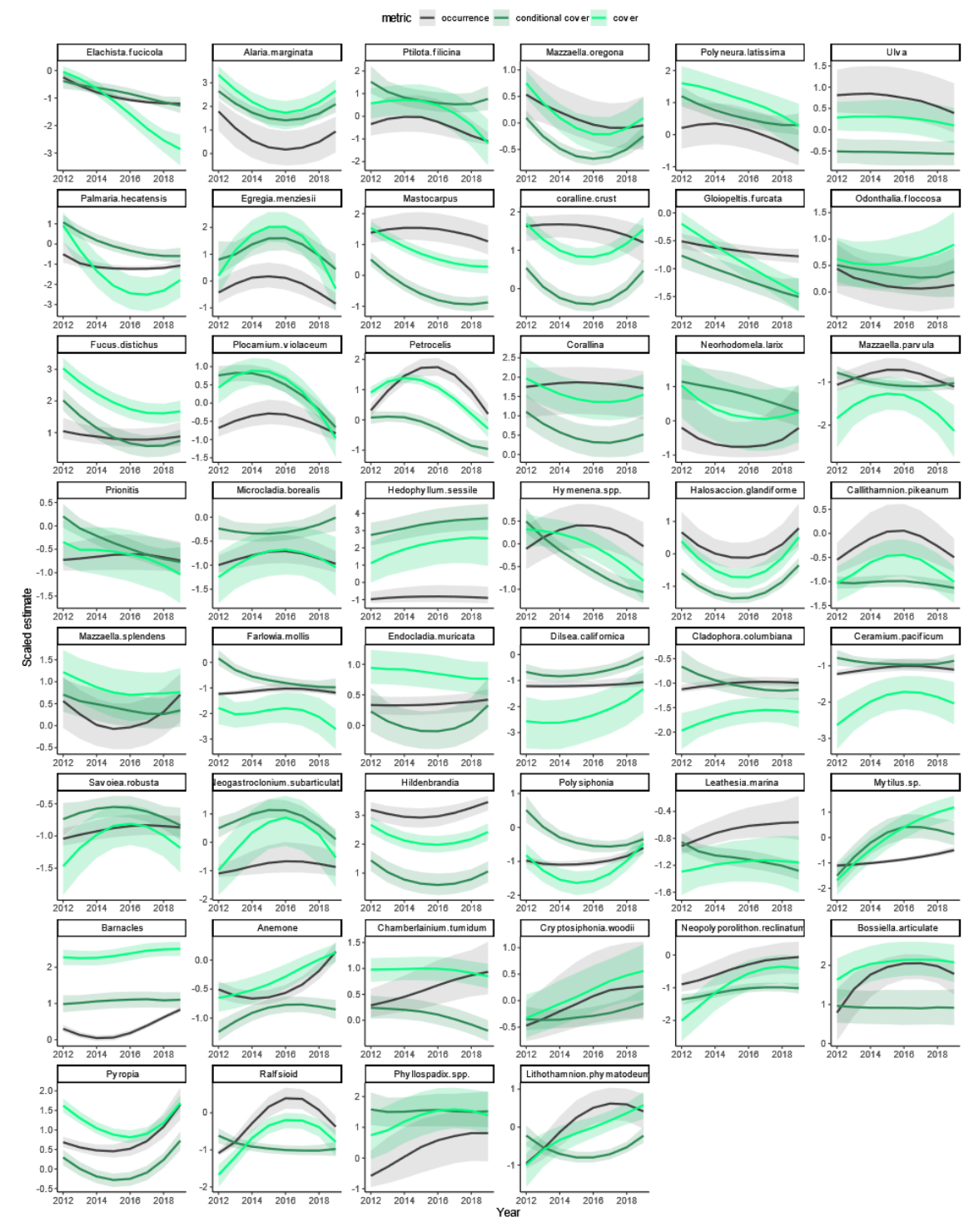

Fig. S8. Predictions from the HMSC hurdle model displaying scaled temporal trends for each taxon. Colors correspond to model metrics. Note that cover is produced by multiplying occurrence by conditional cover. Predictions were averaged over eight uniformly spaced elevations weighted by the frequency (see Fig. S7). 

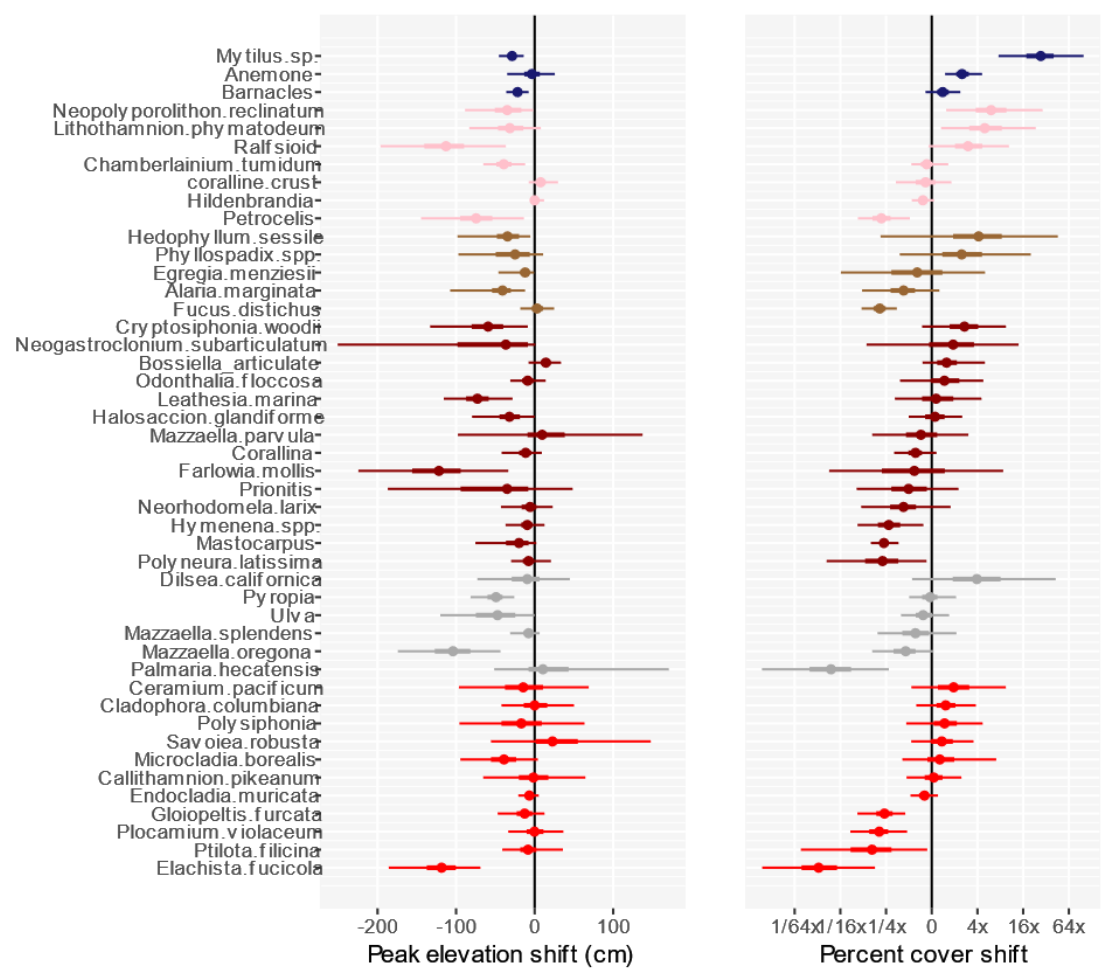

Fig. S9. Shifts in peak elevation (cm) and abundance (fold change) for the 46 taxa we modelled with HMSC, arranged by functional group and then individual trends in occurrence. Points are median shifts across 1,000 posterior samples (shown in Figure 2C), and errors bars are 50\% (thick bars) and 95\% CIs (thin bars). We constrained our predictions to the surveyed elevation range (61 to $382 \mathrm{~cm}$ above MLLWLT), creating a few situations where upper $95 \%$ credible limits for peak elevation shifts were exactly zero (e.g., Egregia menziesii , Ulva ,Halosaccion glandiforme). We do not consider these shifts to be significantly different from zero. Taxa are arranged from the greatest cover loss over time to greatest cover increases, first by functional group (colors as in Fig. 2) and then by taxa within functional groups. 

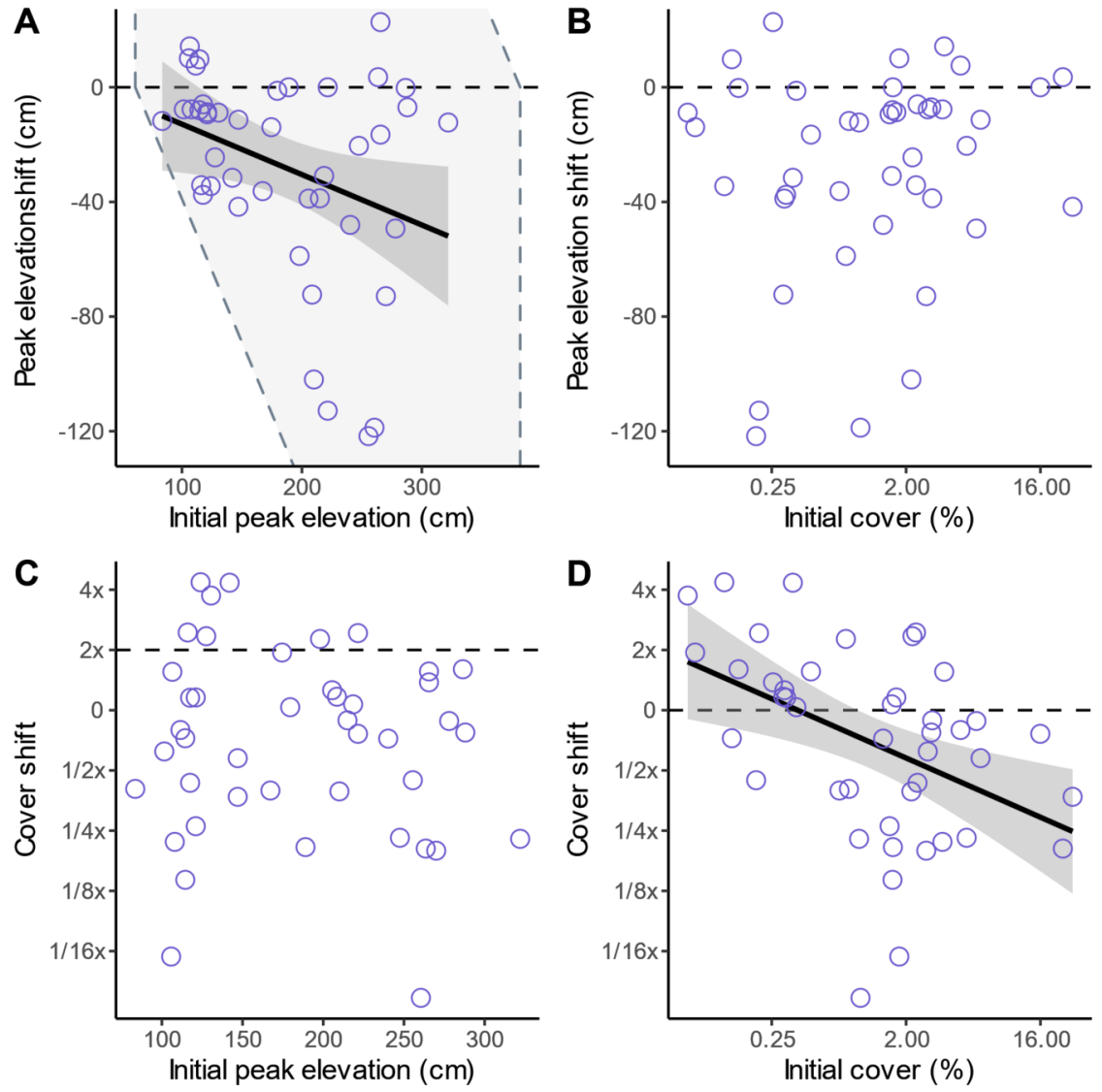

Fig. S10. Relationships among initial states and shifts over time for abundance and elevation as predicted by HMSC. Because our sampling design does not cover the entire elevation/depth distribution of every species, predicted elevational peaks for several species found below the lowest survey points (e.g., surfgrasses) or above the highest points (e.g., barnacles) were beyond the limits of the study area. We decided to restrict our predictions to the boundaries of the survey area. Therefore, the amount each taxon could shift up or down depended on its initial state (bounding box in A). 

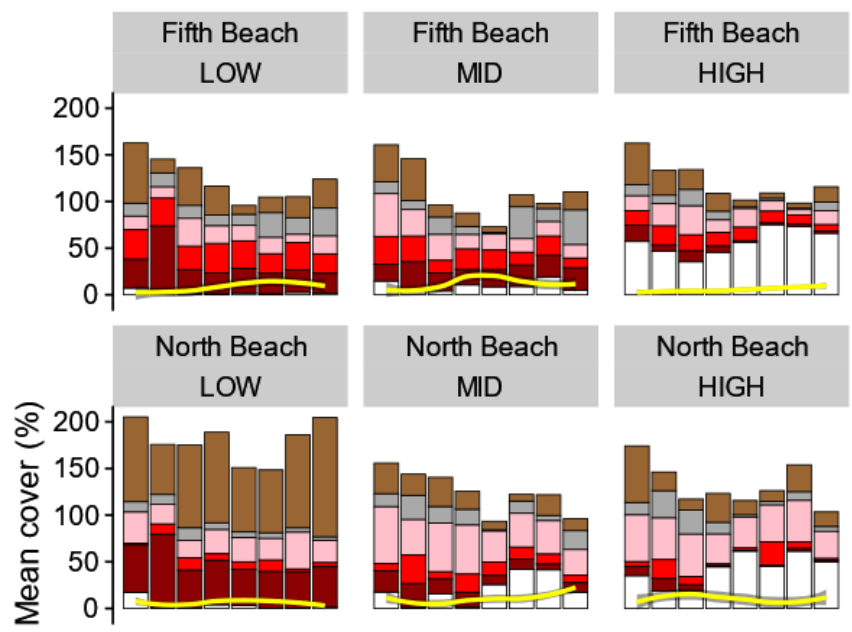

\section{Functional Group}
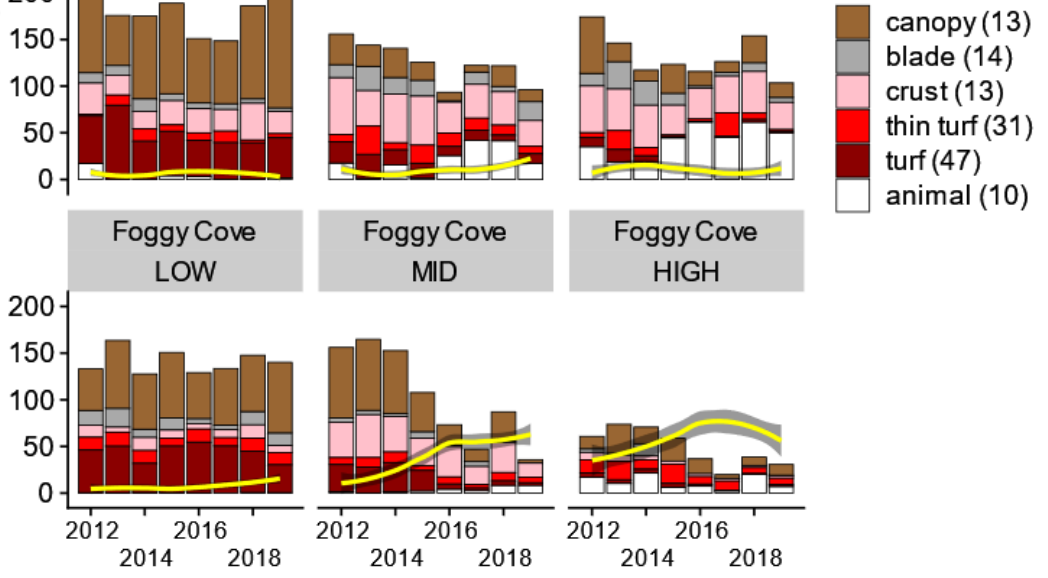

animal (10)

Fig. S11. Comparison of algal functional group dynamics and trends in bare rock cover. Mean abundance within functional groups (bar colors) is shown for each year of the time series. Numbers in parenthesis are counts of taxa in each group. Yellow lines show trends in bare rock cover based on local regressions (LOESS) with shaded $95 \%$ confidence intervals.
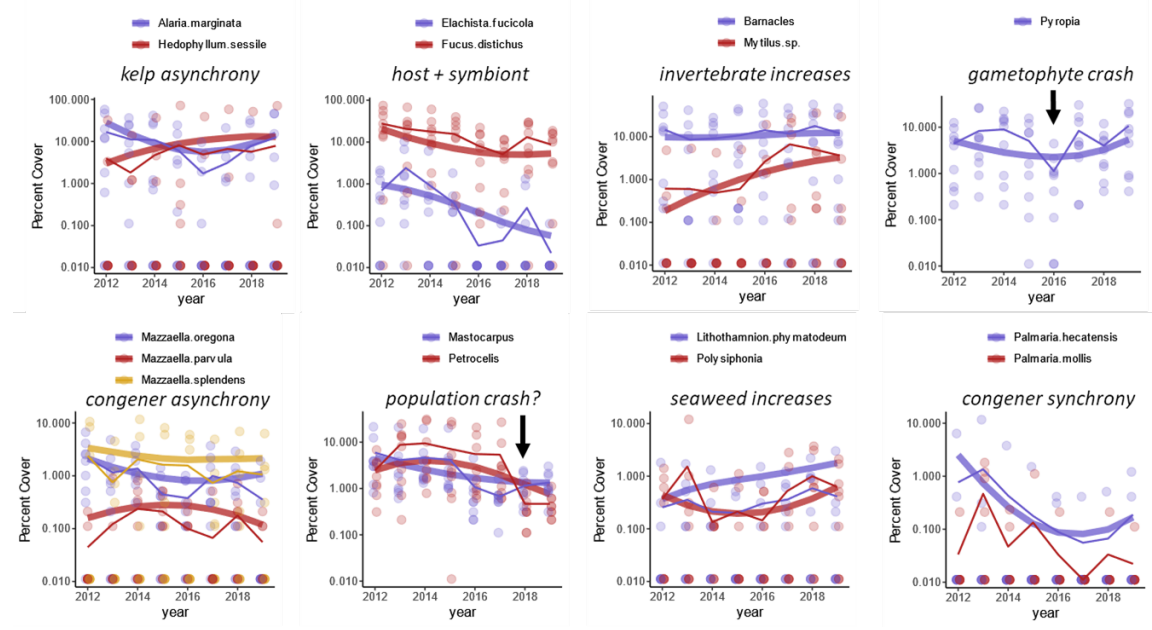

Fig. S12. Select time series of invertebrates and seaweeds observed during surveys. Thin lines show empirical annual means, while thick lines show mean cover predictions for taxa included in the HMSC analysis. HMSC predictions are averages over eight discrete elevations, weighted by their frequency of sampling in the dataset. 


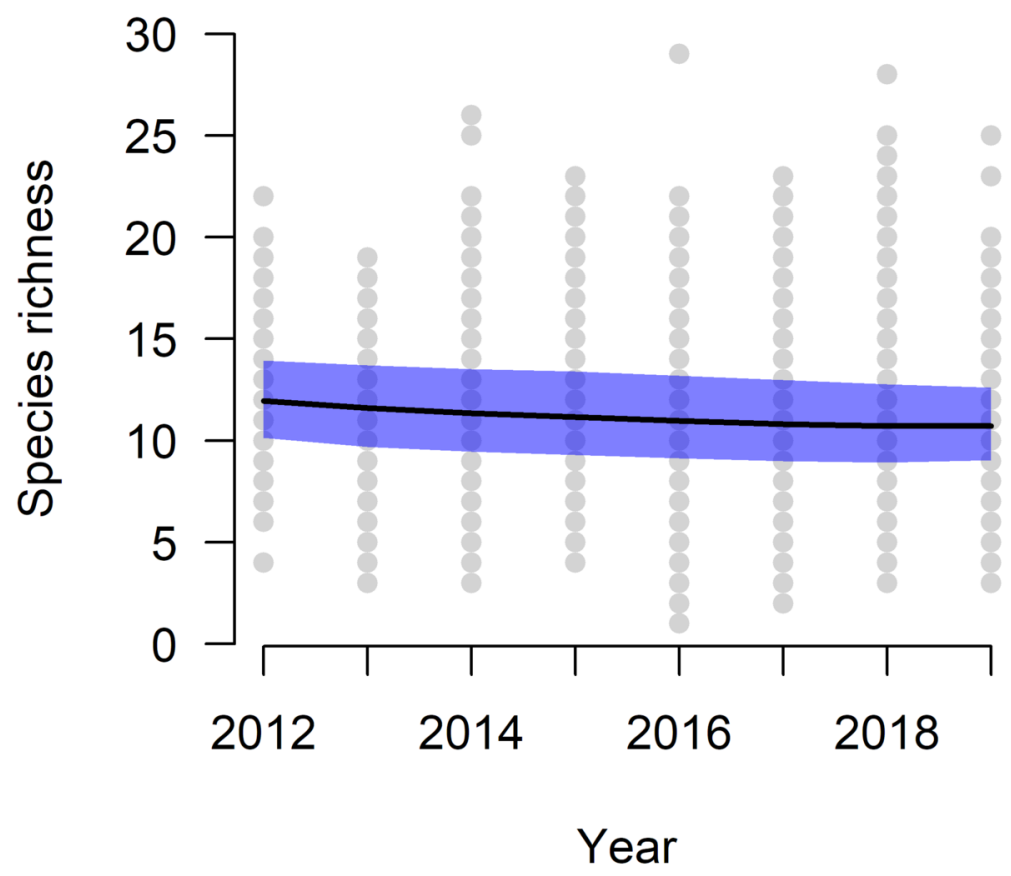

Fig. S13. Species richness estimate from the probit HMSC model (46 of 116 taxa).

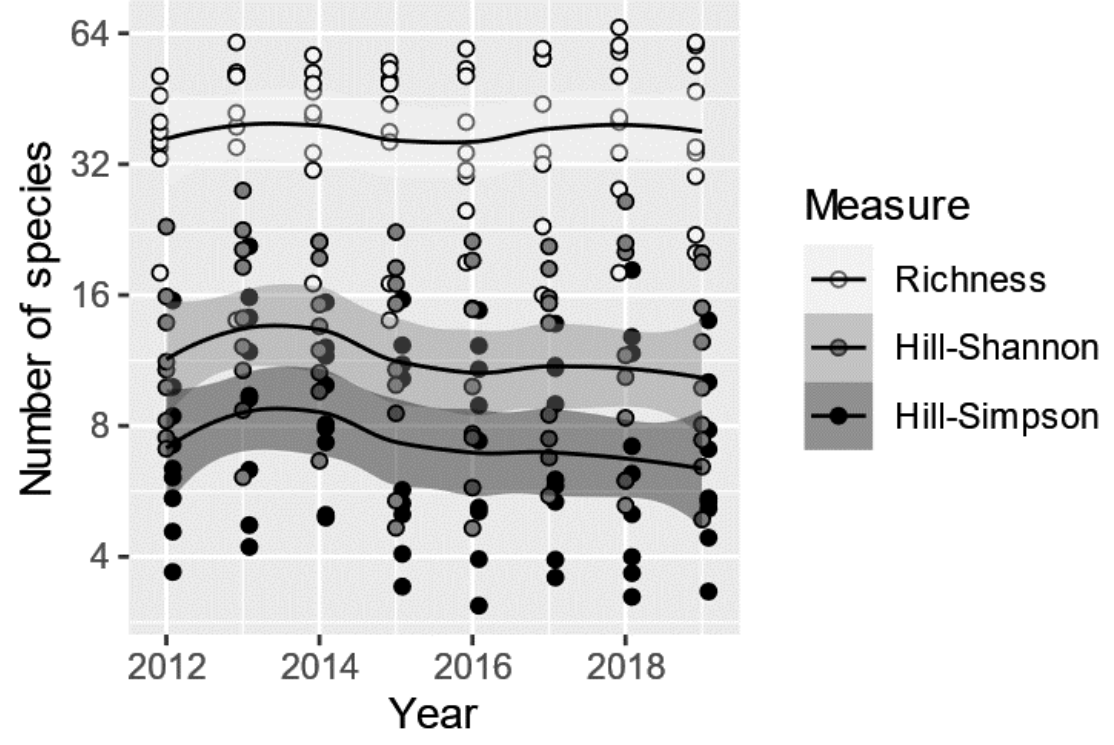


Fig. S14. Patterns of diversity expressed as three Hill numbers: species richness (white), Hill-Shannon index (light grey) and Hill-Simpson index (dark grey). Points are diversity values calculated from mean abundance of each taxon on each transect in each year, and lines show LOESS smooths with $95 \%$ confidence intervals independently fitted for each diversity measure. Note that y-axes are displayed on a $\log _{2}$ scale.

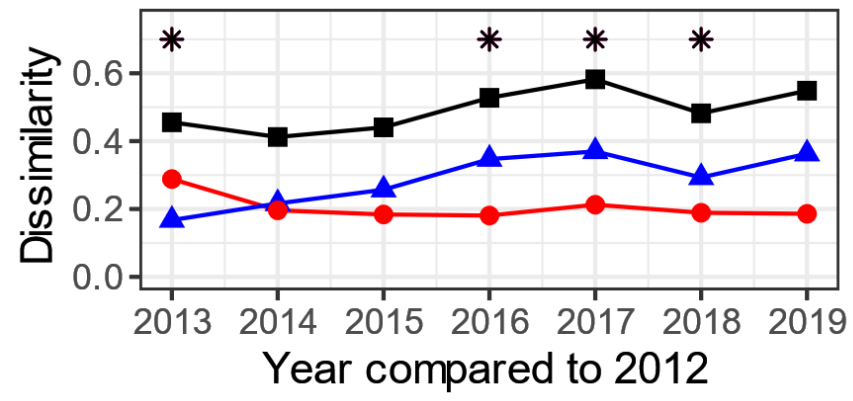

key

- gains

* losses

$\rightarrow$ total

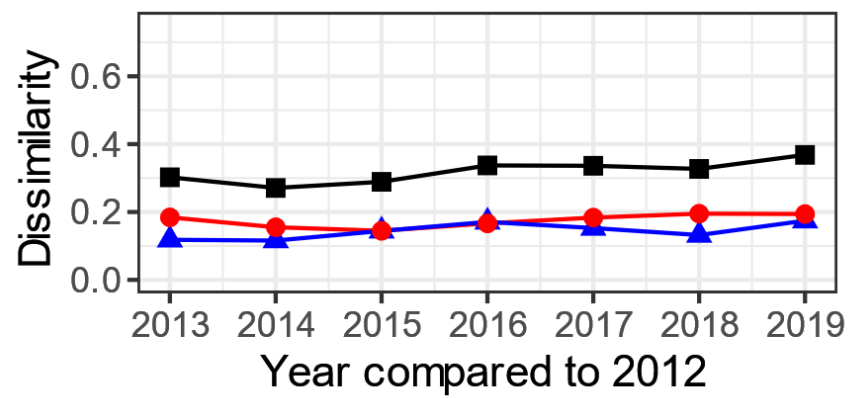

key

$\rightarrow$ gains

- losses

$\rightarrow$ total

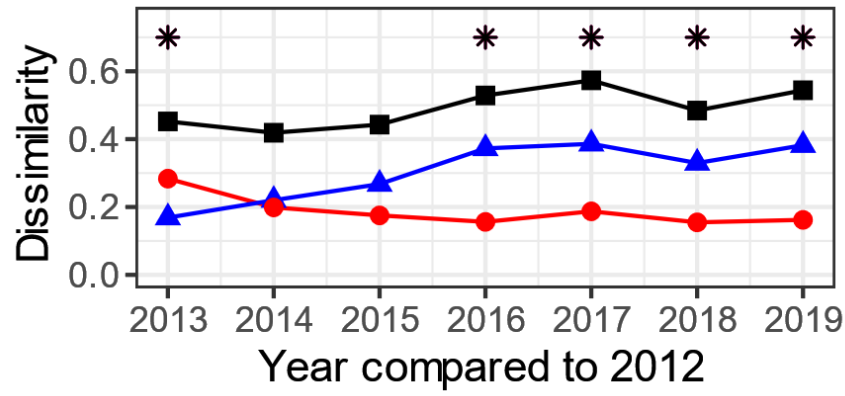

key

- gains

$\rightarrow$ losses

$\rightarrow$ total

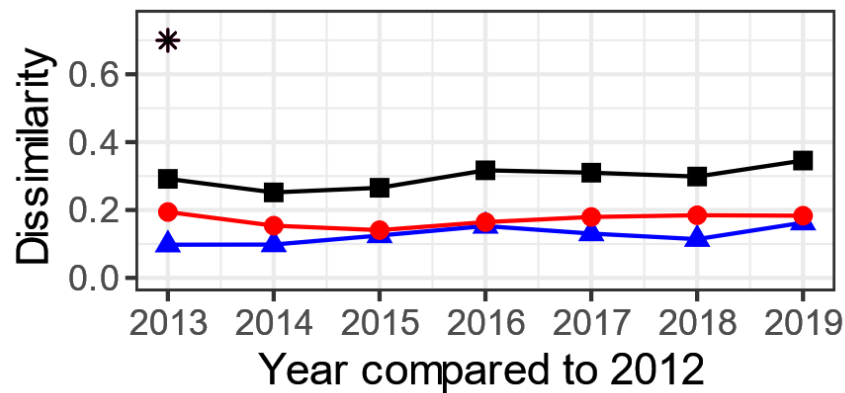

key

- gains

$\rightarrow$ losses

$\rightarrow$ total

Fig. S15. Partitioning of temporal beta diversity indices within transects between years (left panels: all taxa; right: only seaweeds). The survey in 2012 is compared to each subsequent year in the dataset. Changes 
in dissimilarity were calculated using abundance data (top) and presence-absence data (bottom). Asterisks denote significant differences between gains and losses for each pair of years. 